\title{
"People of the Deer"
}

\section{by Farley Mowat. McLelland \& Stewart. 1952}

(Reviewed by Dr. Stuart Houston)

THIS is without a doubt one of the most interesting books that this reviewer has ever read. It is a superb adventure stcry, very well written. But it is much more than this. It is the story of the Caribou and of the little-known and now vanishing tribe of Eskimos who depended on the vast herds of caribou for their livelihood. It portrays the tragic results of the white man's greed, and the calamitous effects of his neglect for the basic principles of conservation. The book is of special ethnological interest, too, because it portrays the life and habits of a tribe of Eskimos who have probably had less contact with the white man than any other native group on this continent. Finally, the book is of interest because the territory it covers includes the far northeastern corner of Saskatchewan, and because its author is a naturalist and former "Blue Jay" contributor, who was raised in Saskatoon.

Farley Mowat was born in 1921 at Belleville, Ont., but the family later moved to Saskatoon where his father became city librarian. Farley spent most of his time, after fours and weekends, mousing about in the swamps and bluffs looking for birds. In 1939 he spent the summer with three other young naturalists studying the fauna of Saskatchewan, and his "Notes on the Birds of Emma Lake, Sask.," recording 156 species, was published in the May 1947 "Crnadian Field-Naturalist." Toward the end of 1939, he enlisted in the Army, was commissioned as a lieutenant and served in England, Sicily and Italy. He served as an Intelligence officer during the invasion of Europe. On discharge from the Army in the spring of 1946, he bought a jeep and came back to Saskatchewan to study the birds at Dundurn and Lac la Ronge. (Members will remember the article he wrote for the Sept. 1946 "Blue Jay" about his observations of that summer.) 1947 and 1948 were spent in the arctic Barren Lands, studying the Ilhamuit, the People of the Deer. He is now married and living at Palgrave, Ont.

Mowat's book is currently becoming a best-seller in the United States, and is a book that no Canadian should miss reading. It is published in Canada by McLelland and Stewart and may be obtained through any book store.

\section{Appreciation}

\section{Ronald Hooper - Somme}

$\mathbf{M}^{\mathrm{y}}$ brother and I are amateur ornithologists and taxidermists. After being advised by $\mathrm{Mr}$. Fred Bard, the Director, we recently made a trip to the Provincial Museum in Regina.

Readers are missing a great deal if they have not visited this museum. Seeing it gave us many ideas for improving our taxidermy work. We were invited into the preparation room and did some mounting, using improved methods taught to us by Fred Lahrman, Mr. Bard's taxidermist.

We were encouraged to proceed with nature photography. The 35 m.m. Retina camera was recommended. This is a "honey" of a camera which is relatively cheap in spite of its efficiency.
We greatly appreciate the willing co-operation of the museum staff in helping amateur naturalists.

\section{NATURE NOTES FROM SPRUCE DALE FARM}

\section{(Continued from Page 11)}

and Blue-winged Teal, Mallard, Golden-eye, and Baldpate.

You can see a big bear crossing from one bluff to another; a deer standing out in the open field, to get away from the flies which torment it in the thick forest growth; a Vireo or a Robin singing from the top of a sixty or seventy foot aspen tree. A few fleecy clouds may be floating across a rich blue sky, and the hum of many kinds of farm tractors can be heard in every direction-such is a spring day in Saskatchewan's North Country. 